\title{
THE RELATION OF MATERNAL DIET TO BREAST FEEDING
}

BY

\author{
J. H. EBBS, M.D., D.C.H.
}

(From the Department of Paediatrics, University of Toronto, and Hospital for Sick Children, Toronto, under the direction of Alan Brown, M.D., F.R.C.P.)

AND

HELEN KELLEY, R.N.

Supervisor of Nurses, Burnside Obstetrical Department, Toronto General Hospital.

The importance of successful breast feeding in the growth, development and welfare of the infant is well recognized. Many observations have been made of the quality of the breast milk resulting from and dependent upon the mother's diet during lactation. It is the purpose of this communication to show how the prenatal diet can also affect the ability of the mother to nurse her infant successfully.

The details of a study of the effect of prenatal diet upon the mother and child have been published recently (Ebbs et al., 1941, 1942). Three groups of low-income expectant mothers attending the prenatal clinic kept diaries of their food intake for one week. These were analysed and three groups of patients were formed. One group found to have poor diets about the fourth or fifth month of pregnancy and who had low incomes were divided by leaving each alternate patient on her poor diet and by supplying the others with certain simple foods daily. Many patients were found to have moderately good diets and a fairly adequate income. They were given advice about improving their diet. Thus one group of one hundred and twenty women were left on their poor diets throughout pregnancy and are called the ' poor diet group.' Another group of ninety women who were found to have a poor diet were given extra food from the fourth or fifth month of pregnancy until the baby was six weeks old. They are referred to as the 'supplemented group.' A third group of one hundred and seventy women were given advice and their diets improved by education, forming a ' good diet group.'

The supplemented group were provided with the following foods daily: $30 \mathrm{oz}$. milk, one egg, $1 \mathrm{oz}$. cheese, one orange, $4 \frac{1}{2} \mathrm{oz}$. canned tomatoes, 2 tablespoons of wheat germ, and 1 viosterol capsule containing 2000 units of vitamin D. They were given advice about the other foods necessary to ensure a wellbalanced diet, to be provided from their own income. 
Analyses of food diaries kept by each patient at the beginning of the period of observation and again one month before confinement show the marked improvement in some of the important food elements brought about in the supplemented group by adding the above foods to a poor diet, and in the good diet group by education alone (table 1 ).

TABLE I

PERCENTAGE OF PATIENTS IN EACH GROUP ON BASIS OF DAILY CONSUMPTION OF PROTEIN, CALCIUM AND VITAMIN C (CITRUS FRUIT AND TOMATO)

\begin{tabular}{|c|c|c|c|c|}
\hline & & $\begin{array}{c}\text { PROTEN } \\
\text { MORE THAN } 80 \mathrm{GM} .\end{array}$ & $\begin{array}{c}\text { CALCIUM } \\
\text { MORE THAN } 1.2 \mathrm{GM} .\end{array}$ & $\begin{array}{c}\text { VITAMIN C } \\
\text { MORE THAN } 50 \text { MGM. }\end{array}$ \\
\hline Poor Diet & $\begin{array}{l}\text { 1st analysis } \\
\text { 2nd analysis }\end{array}$ & $\begin{array}{r}7 \\
14\end{array}$ & $\begin{array}{r}3 \\
11\end{array}$ & $\begin{array}{l}1 \\
0\end{array}$ \\
\hline Supplemented & $\begin{array}{l}\text { 1st analysis } \\
\text { 2nd analysis }\end{array}$ & $\begin{array}{r}5 \\
78\end{array}$ & $\begin{array}{r}4 \\
88\end{array}$ & $\begin{array}{r}1 \\
50\end{array}$ \\
\hline Good Diet & $\begin{array}{l}\text { 1st analysis } \\
\text { 2nd analysis }\end{array}$ & $\begin{array}{l}37 \\
74\end{array}$ & $\begin{array}{l}22 \\
61\end{array}$ & $\begin{array}{r}8 \\
10\end{array}$ \\
\hline
\end{tabular}

It will be noted that the percentage of patients in the poor diet group who were receiving more than the minimum requirements of protein, calcium and vitamin $\mathrm{C}$ was low and remained relatively low in the second analysis, whereas there was marked improvement in the second analysis of the supplemented and the good diet groups. The average vitamin $B_{1}$ content of the poor diets was 324 units daily, which was increased to 774 units when the extra food was supplied to the supplemented group

Observations of the whole course of pregnancy were made in order to compare the three groups of patients. The details of the obstetrical and paediatric findings have been published elsewhere (Ebbs, Scott et al., and Ebbs, Brown et al., 1942). During the prenatal period, during labour and during convalescence there were more complications in the poor diet group than in the other two groups. The general condition of the mothers in the better-fed groups was noticeably better and they were considered to be better obstetrical risks than those left on their poor diets. During convalescence in the hospital 12 per cent. of the patients in the poor diet group were considered to be in poor condition, compared with 4 per cent. of the supplemented group and 9 per cent. of the good diet group. The incidence of mastitis was twice as great in the poor diet group, compared with the supplemented group. The good diet group also showed a higher incidence of breast inflammation. The number of patients is too small to draw any definite conclusions, but mastitis is certainly a factor which interferes with successful breast feeding.

The supervisor of nurses at the maternity hospital where these women were confined has recorded in a large group of cases her findings with regard to the ability of the mother to nurse her infant (Ebbs, Brown et al., 1942). This was done without the diet groups of the patient being designated (table 2). Good rating indicates successful breast feedings. Fair rating is used when supple- 
TABLE 2

THE ABILITY OF THE MOTHER TO NURSE THE INFANT IN THE HOSPITAL (Ebbs, Brown et al., 1942)

\begin{tabular}{|c|c|c|c|c|c|}
\hline & & & GOOD PER CENT. & FAIR PER CENT. & POOR PER CENT. \\
\hline $\begin{array}{l}\text { Poor diet } \\
\text { Supplemented diet } \\
\text { Good diet } \quad \text {. }\end{array}$ & $\begin{array}{l}\cdots \\
\cdots \\
\cdots\end{array}$ & $\begin{array}{l}\cdots \\
\cdots\end{array}$ & $\begin{array}{l}42 \\
52 \\
49\end{array}$ & $\begin{array}{l}41 \\
42 \\
43\end{array}$ & $\begin{array}{r}17 \\
6 \\
8\end{array}$ \\
\hline
\end{tabular}

mental feeding is necessary and the progress of the baby is not as rapid as normal. Poor indicates very slow progress, marked loss of weight on breast milk, poor supply of breast milk, or artificial feeding. When the mother returned for examination at the postnatal clinic, six weeks after delivery, the type of feeding and the progress of the baby was recorded. When the baby was brought for examination at the age of six months, the details of the duration of breast feeding were completed. Table 3 contains the percentage of babies in each group being breast fed up to the age of two weeks, whether still in the hospital or at home, and the incidence throughout the first six months of life. This is further illustrated in the graph (chart I).

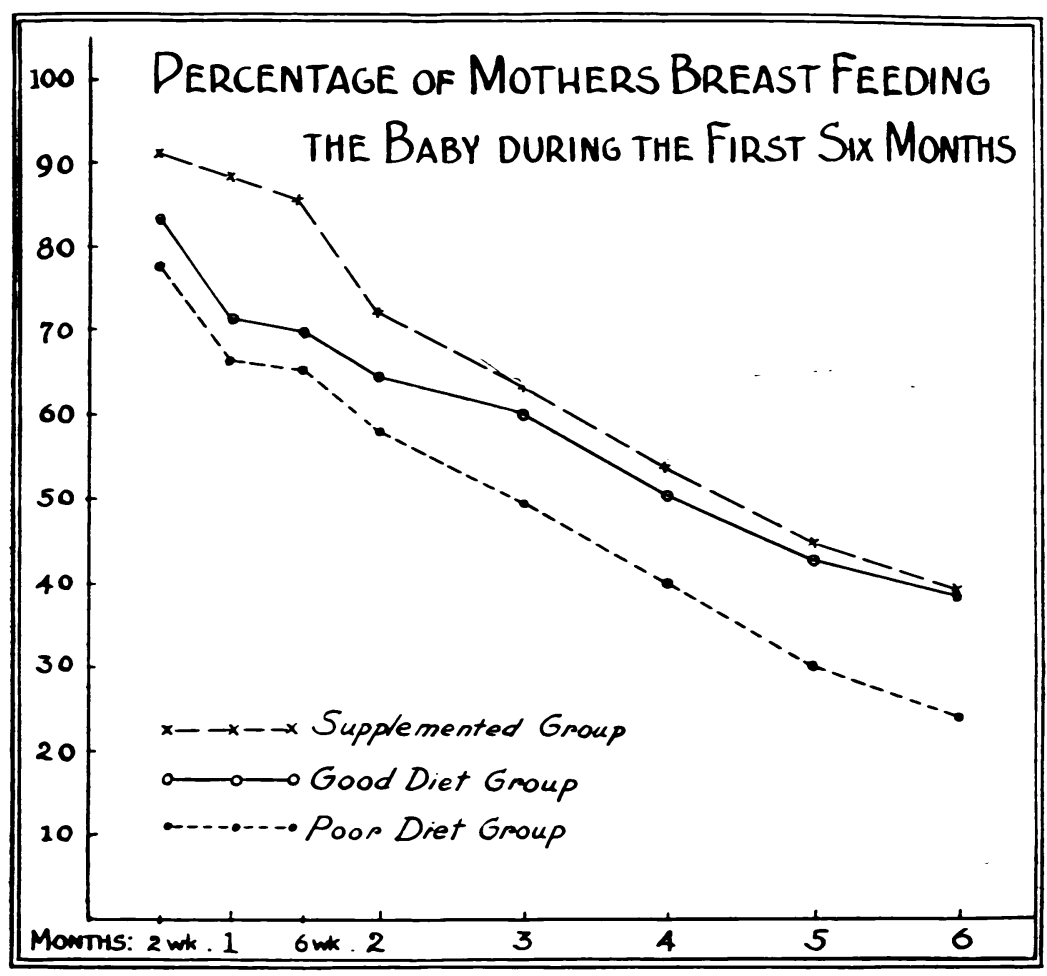

Chart I

Upon leaving the hospital, between the tenth and fifteenth day after delivery, there was a noticeable drop in the incidence of breast feeding, being more 
marked in the poor and the good diet groups. After six weeks there was a marked drop in the number of babies in the supplemented group who were breast fed. The extra food being sent to this group was stopped when the baby was six weeks old. This seems to have influenced the ability of some of the mothers to continue the nursing period. Throughout the remaining period up to six months, the incidence of breast feeding was about the same in the supplemented and good diet groups, but was higher than in the poor diet group.

TABLE 3

INCIDENCE OF BREAST FEEDING UP TO SIX MONTHS (Percentages)

\begin{tabular}{l|l|l|l|l|l|l|}
2 & WEEKS & 1 MONTH & 6 WEEKS 2 MONTHS 3 MONTHS 4 MONTHS 5 MONTHS 6 MONTHS
\end{tabular}

\begin{tabular}{|c|c|c|c|c|c|c|c|c|}
\hline Poor diet & 78 & 67 & 65 & 58 & 49 & 40 & 30 & 24 \\
\hline $\begin{array}{l}\text { Supplemented } \\
\text { diet }\end{array}$ & 91 & 89 & 86 & 72 & 63 & 54 & 44 & 39 \\
\hline Good diet & 84 & 72 & 70 & 65 & 60 & 50 & 43 & 38 \\
\hline
\end{tabular}

At six months of age the babies born of mothers in the supplemented and good diet groups were found to average a slightly higher weight than the babies of mothers in the poor diet group, and they had suffered from fewer illnesses. This might have resulted from better conditions at birth as a result of the mother's prenatal diet and from the increased incidence of breast feeding in the two well-fed groups.

\section{Discussion}

Robinson (1941) found in a study of the incidence of breast feeding in ten classes of the population that the greatest decline in breast feeding occurs in the first month among the wives of labourers in England, and that continued poverty lowers the ability of the mother to keep the baby on the breast through the first month. In another communication, Robinson (1939), states that the incidence of breast feeding is lowest in depressed industrial areas. That poverty is not the only factor in successful breast feeding is well recognized, since many who can and do afford a good prenatal diet do not nurse their infants, but poverty goes hand-in-hand with poor diet, which results in weakness and lack of proper health. By supplying food to the women in the study which has been described, it was noted that when the diet changed from a very poor one to a diet which at least contained the fundamentals of normal requirements, these women not only improved physically, but also mentally. Their attitude towards the outcome of the pregnancy, which formerly was one of apathy, soon became one of normal interest. This attitude seemed to be carried over into the postnatal nursing period. The sudden drop in the incidence of nursing in the supplemented group at six weeks might be explained by the change in mental attitude of the mother when the food was stopped, or it might have been the result of the sudden withdrawal of certain food factors which have 
been suggested as influencing the secretion and the quality of breast milk. It is also recognized that nutrition is not the only factor concerned with successful breast feeding.

\section{Summary}

A comparison of the incidence of breast feeding in three groups of low-income class mothers has been made. The group which was supplied with extra food and the group which was educated to provide a good prenatal diet were more successful in nursing their infants than the mothers who had been left on poor prenatal diets. The effect of postnatal diet upon nursing was evident by a decrease in the percentage of breast-fed babies when extra food was stopped six weeks after the birth of the baby. The relation of poverty to poor prenatal diets and its effect upon the incidence of breast feeding and the development of the infant are pointed out.

\section{REFERENCES}

Ebbs, J. H., Tisdall, F. F., and Scott, W. A. (1941). J. Nutrit., 22, 515.

—, Scott, W. A., Tisdall, F. F., Moyle, W., and Bell, M. (1942). Canad. med. Ass. J., 46, 1.

-, Brown, A., Tisdall, F. F., Moyle, W., and Bell, M. (1942). Loc. cit., 6.

Robinson, M. (1939). Arch. Dis. Childh., 14, 259.

- (1941). Ibid., 16, 31. 